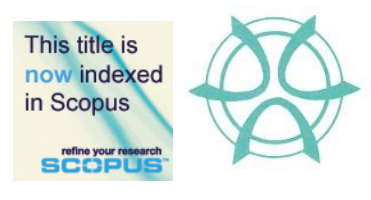

PLANNING MALAYSIA:

Journal of the Malaysian Institute of Planners

VOLUME 15 ISSUE 4 (2017), Page 57 - 68

\title{
SUSTAINABLE FOOD WASTE MANAGEMENT IN HOTELS: CASE STUDY LANGKAWI UNESCO GLOBAL GEOPARK
}

\author{
Saraswathy Kasavan', Ahmad Fariz Mohamed², \& Sharina Abdul Halim³ \\ ${ }^{1,2,3}$ Institute for the Environment and Development \\ UNIVERSITI KEBANGSAAN MALAYSIA
}

\begin{abstract}
The hotel sector is one of the key players in developing tourism industry in the islands, and contributing towards islands economy, employment opportunities and the overall development. However, food waste generated by hotels has significantly impacted the environment, social well-being and tourism economy. Sustainable food waste management practices are vital among the business operations of the hotel sector to reduce food waste and operational costs through efficient use of food resources. The aim of this paper is to examine current practice of hotel operators towards sustainable food waste management from purchasing of food resources to food wastes disposal. The data was gathered using structured and self-administered questionnaires, which involved 42 hoteliers from the island of Langkawi UNESCO Global Geopark. From the main findings, it was found that there was a lack of emphasis from the hotels on their policy related to wastage of food and unsustainable food consumption pattern by their guests. This reflects on the lack of practices towards sustainable food waste management by the hotel sector. Therefore, planning for sustainable food waste management on island hotels is essential to ensure the protection of environmental resources and to reduce the problem regarding limited capacity landfills on the islands
\end{abstract}

Keyword: Food waste, geopark, hotel, island, practice, sustainable food waste management

Date Received: $7^{\text {th }}$ July 2017

Date of Acceptance: $6^{\text {th }}$ November 2017 
Saraswathy Kasavan, Ahmad Fariz Mohamed, \& Sharina Abdul Halim

Sustainable Food Waste Management in Hotels: Case Study Langkawi Unesco Global Geopark

\section{INTRODUCTION}

The tourism sector is a booming industry in almost every country globally. Apart from the export of various commodities internationally, most of the countries are now prioritizing tourism as one of the main sources of income through foreign exchange (Kasimu, Zaiton \& Hassan, 2012). The Statistics of Tourism Malaysia 2016 indicated that the tourism sector is the third largest revenue contributor at RM82.1 billion for Malaysia economy (Tourism Malaysia, 2017). Environmental resources and unique nature of islands have become attractive tourism products and have contributed largely to the development of the Malaysian tourism industry. A majority of the islands are blessed with environmental resources; such as warm climate, crystal beaches, geological features and clean air (Mensah \& Blankson, 2014).

The hotel sector is one of the key players in developing the tourism industry in the islands that contributes to local economy as well as providing employment opportunities. However, the lack of proper management among the business operations of the hotel sector may lead to damages on the islands' environment, and then lose out on tourism and economic activities (Bohdanowicz, 2005; Mensah \& Blankson, 2014).

Being one of the largest food consumers, hotels generate a large amount of food waste every day (Agamuthu Pariatamby \& Nagendran Periaiah, 2007; Papargyropoulou et al., 2016; Sandaruwani \& Gnanapala, 2016). WRAP (2011) found that almost $50 \%$ of food waste produced from total solid waste was generated by the hotel industry. This clearly shows that there is a serious sustainability issue regarding food waste from the hotel sector. Moreover, islands are highly vulnerable and sensitive towards any environmental changes and impacts, particularly from any unsustainable practices of food waste. Therefore, sustainable food waste management on island hotels is essential to ensure the protection of environmental resources and reduce the problem regarding limited capacity landfills on the islands. Additionally, hotel operators should also pursue practices of sustainable food waste management because resources for foodstuff also take a larger portion of the hotel's operation cost.

Previous studies have indicated that hoteliers are mainly focusing on sustainable practices for water, electricity, and recyclable solid waste, such as bottles, can, paper, and plastics (Kasim, 2009; Kasimu, Zaiton, \& Hassan, 2012; Molina et al., 2009; Pirani \& Arafat, 2015). Meanwhile, documentation on hoteliers' practices towards sustainable food waste management have not been specifically given great attention by previous researchers and hence, the need for this study, particularly for Langkawi Island.

The aim of this paper is to examine current practice of hotel operators in Langkawi Island towards sustainable food waste management from purchasing of food resources to food wastes disposal. The contribution of this study can provide a comprehensive description of the current practices of food waste 
management for the hotel sector on islands and most of the wasteful processes could be identified. This can evidently guide the waste minimisation strategy by informing where the focus should be and which recommendations could have a greater impact in reducing food waste.

\section{RESEARCH APPROACH}

\section{Study Area}

Langkawi Island is situated at the Andaman Sea within $30 \mathrm{~km}$ off the mainland coast of the north-western corner of Peninsular. Langkawi is also one of the districts in the state of Kedah, Malaysia and is blessed with unique geological features, biodiversity, cultural heritage, and environmental resources. The declaration of Langkawi as a duty-free island in 1987 is considered a major evolution of economies from the agriculture and fisheries sector to the service sector and has become the turning point for rapid tourism development for this island (Sharina Abdul Halim et al., 2011). In 2007, Langkawi became the first UNESCO Global Geopark in the Southeast Asia and the $52^{\text {nd }}$ member in the world (Ong et al., 2010). Langkawi took the centre stage to be one of international tourism destinations by hosting world class events such as Langkawi International Maritime and Aerospace Exhibition (LIMA), Royal Langkawi International Regatta, Ironmen Langkawi International Triathlon, and Le Tour De Langkawi (Azizan Marzuki et al., 2016). Thus, this leads Langkawi to become a popular destination for domestic and international tourists. Tourist arrivals in Langkawi has increased from 2.4 million in 2010 to 3.6 million in 2016 (LADA, 2017).

Several new hotels have emerged in order to cope with the developing tourism industry in Langkawi. However, Agamuthu Pariatamby \& Nagendran Periaiah. (2007) found that Langkawi has one of the highest food waste generation among the tourist islands in Malaysia and in great need for a systematic effort to reduce waste generation. Furthermore, tourists in Langkawi generated waste per capita more than double as compared to the local residents (Shamshiry et al., 2011). Similarly, Wang et al. (2017) found that, generally, food waste per capita per meal for tourists is higher than local residents.

With a status of UNESCO Global Geopark, Langkawi needs to apply the practices of sustainable food waste management not only at the household level but also for the hotel sector. Therefore, hoteliers should apply the practices of sustainable food waste management to maintain balance between environmental conservation and tourism development.

\section{Method}

In this study, a quantitative data collection method was used to identify the practices that could lead towards sustainable food waste management in the hotel sector. The data was collected using questionnaires to obtain information on the 
Saraswathy Kasavan, Ahmad Fariz Mohamed, \& Sharina Abdul Halim

Sustainable Food Waste Management in Hotels: Case Study Langkawi Unesco Global Geopark

current hoteliers' practices and participation towards sustainable food waste management. The study focuses on selected hotels that provide accommodation together with food and beverage services. The list of hotels on the island of different categories, ranging from 1 star to 5 star hotels, was collected from various website resources such as the Malaysian Association of Hotels (MAH), Langkawi Municipal Council and travel agencies (Agoda and Trivago). All together 56 hotels were identified and all were selected as sample in this study.

A few completed copies of the questionnaire were collected through online surveys, while most of the other questionnaires were personally collected by the researchers. In total, 42 questionnaire forms were received from the total population of 56 hotels.

Normally, hotel food management operations and personnel vary between hotels, depending on the star category of the hotels. Hence, for this research, several different respondents holding different positions were chosen such as chef, steward, operation manager, general manager, and F\&B manager. The questionnaire was a self-constructed close-ended questionnaire using the 5 Likert scale to measure current level of hotels' participation in food waste management. The statistical methods used in this study were mainly descriptive statistics of min and standard deviation. To assess the level of practices towards sustainable food waste management, the interpretation of mean score by Ahmad (2002) was adapted (Table 1).

Table 1 Interpretation of the trend level of mean score

\begin{tabular}{ll}
\hline Score & Interpretation \\
\hline $3.68-5.00$ & High \\
$2.34-3.67$ & Moderate \\
$1.00-2.33$ & Low \\
\hline Source: Ahed 2002
\end{tabular}

\section{RESULTS AND DISCUSSIONS}

Table 2 shows the profiling of the hotels (type of ownership, type of hotel ranking, and number of guestrooms). The total number of respondents was 42 (28 males and 14 females). A majority of the hotels (61.9\%) were independently owned, or self-managed. About $23.8 \%$ of hotels were chain-owned, and this is followed by $9.5 \%$ that were independently-owned, managed by a franchise agreement. Normally, type of hotel ownership influence the type of hotel operations regarding food waste management. This is because chain-owned hotels usually have their own specific guidelines for waste management compared to self-managed hotels. Based on the questionnaire, the majority were 3 star hotels (33.3\%), followed by 4 star hotels (21.4\%). Only 19\% were 1 star hotels and $14.3 \%$ were 2 star hotels. Only $11.9 \%$ of the hotels were 5 stars. 
PLANNING MALAYSIA

Journal of the Malaysia Institute of Planners (2017)

Table 2 Profiling of the hotels

\begin{tabular}{llrr}
\hline & & $\begin{array}{c}\text { Frequency } \\
(\mathrm{N}=42)\end{array}$ & \multicolumn{2}{c}{$\begin{array}{c}\text { Percent } \\
(\%)\end{array}$} \\
\hline Type of ownership & $\begin{array}{l}\text { Independently owned, self-managed } \\
\text { Independently owned, managed by a } \\
\text { franchise agreement }\end{array}$ & 26 & 61.9 \\
& $\begin{array}{l}\text { Independently owned, managed by a } \\
\text { management contract }\end{array}$ & 4 & 9.5 \\
& Chain owned, managed by the chain & 10 & 4.8 \\
& 1 star hotel & 8 & 19.0 \\
\hline Type of hotel & 2 star hotel & 6 & 14.3 \\
ranking & 3 star hotel & 14 & 33.3 \\
& 4 star hotel & 9 & 21.4 \\
& 5 star hotel & 5 & 11.9 \\
\hline
\end{tabular}

\section{Hotel Participation in Sustainable Food Waste Management}

The main aim of this study is to examine the practices towards sustainable food waste management, beginning from the process of purchasing to disposal, which are most commonly adopted by hoteliers in Langkawi. The process of purchasing food ingredients is a preliminary process and it is the starting point for sustainable food waste management for the hotel sector. In Langkawi, most of the food ingredients arrive via cargo from mainland Kuala Perlis and Kuala Kedah. The food ingredients are delivered to the hoteliers via suppliers or purchased by ownself at nearby markets. Commonly, small hoteliers buy food ingredients on their own and do not require a particular supplier because they need to prepare meals for a small number of guests. Therefore, they have the opportunity to choose food ingredients that are fresh and of good quality. Meanwhile, the larger hoteliers buy their needed raw food ingredients via particular suppliers. These hoteliers will select their suppliers according to a few qualifications such as product quality, timely delivery, ability to support the required quantity, consistency of products, and price (Mourad, 2016; Tan, Lyman \& Wisner, 2002). The hoteliers will send the products back to their suppliers if the products received were broken or in damaged condition as they must always ensure that the delivery of raw food ingredients are in good condition. Generally, the entire purchase process is controlled by the hoteliers making sure to prevent waste due to spoilage at an early stage. Therefore, the findings reveal that the interpretation of all the items for the process of purchasing practices is high, which is above mean 4.36 (Table $3)$. 
Saraswathy Kasavan, Ahmad Fariz Mohamed, \& Sharina Abdul Halim

Sustainable Food Waste Management in Hotels: Case Study Langkawi Unesco Global Geopark

Table 3 Practices towards sustainable food waste management

\begin{tabular}{|c|c|c|c|}
\hline Construct items & Min & SD & Interpretation \\
\hline \multicolumn{4}{|l|}{ Purchasing } \\
\hline $\begin{array}{l}\text { 1. Only buy the food ingredient according to } \\
\text { needs. }\end{array}$ & 4.55 & .091 & High \\
\hline $\begin{array}{l}\text { 2. Check the food ingredient when } \\
\text { purchasing to ensure that food is not } \\
\text { broken or packaging is not damaged. }\end{array}$ & 4.60 & .084 & High \\
\hline $\begin{array}{l}\text { 3. Check the food ingredient's expiry date } \\
\text { when purchasing. }\end{array}$ & 4.60 & .084 & High \\
\hline $\begin{array}{l}\text { 4. Check what food ingredient is already in } \\
\text { storage before purchasing. }\end{array}$ & 4.48 & .119 & High \\
\hline $\begin{array}{l}\text { 5. Reduce purchasing of food items that are } \\
\text { much discarded. }\end{array}$ & 4.36 & .156 & High \\
\hline \multicolumn{4}{|l|}{ Storage } \\
\hline $\begin{array}{l}\text { 6. Make sure those fresh food ingredients are } \\
\text { stored at the appropriate temperatures. }\end{array}$ & 4.74 & .069 & High \\
\hline $\begin{array}{l}\text { 7. Store the food ingredient in order during } \\
\text { purchase - "first-in, first-out". }\end{array}$ & 4.40 & .137 & High \\
\hline $\begin{array}{l}\text { 8. Label food ingredients that show the } \\
\text { products' expiry dates before being stored. }\end{array}$ & 4.40 & .132 & High \\
\hline $\begin{array}{l}\text { 9. Label food ingredients that show the } \\
\text { storage instructions before storage. }\end{array}$ & 4.31 & .134 & High \\
\hline $\begin{array}{l}\text { 10. Ensure the food ingredient storage area is } \\
\text { safe (avoid spills, broken and damaged } \\
\text { products). }\end{array}$ & 4.60 & .091 & High \\
\hline
\end{tabular}

Food preparation

11. Make extra food in case it is needed only. $4.36 \quad .136 \quad$ High

12. Reduce using food ingredients that are $\quad 4.02 \quad .162 \quad$ High easily damaged for preparing food.

13. Consider guests' demands when preparing $\quad 4.07 \quad .150 \quad$ High food.

14. Use the leftover quality food for the $\quad 2.88 \quad .184 \quad$ Moderate preparation of other meals.

15. Prepare a variety of sizes of portion meals. $\quad 3.95 \quad$.144 $\quad$ High

Serving food

16. Waiter will give a clear explanation about $\quad 4.26 \quad \begin{array}{llll}128 & \text { High }\end{array}$ the cooking method to the guests while taking food orders.

17. Waiter will give a clear explanation about the food ingredients used to the guests while taking food orders.

18. Waiter will give a clear explanation about the size portion of food served to the guests while taking food orders.

19. Provide training for waiters to perform clear communication about menu order to the chef. 
PLANNING MALAYSIA

Journal of the Malaysia Institute of Planners (2017)

20. Provide various portions to guests to $\quad 3.90 \quad .166 \quad$ High choose the size of dish required.

\begin{tabular}{|c|c|c|c|}
\hline \multicolumn{4}{|l|}{ Management of leftover food and guests' plat waste } \\
\hline 21. Use the leftover foods as animal feed. & 3.02 & .197 & Moderate \\
\hline 22. Donate leftover quality food to charity. & 2.67 & .173 & Moderate \\
\hline $\begin{array}{l}\text { 23. Let staff take home the leftover quality } \\
\text { foods. }\end{array}$ & 2.98 & .194 & Moderate \\
\hline $\begin{array}{l}\text { 24. Extra charge to guests who leave food on } \\
\text { their plates. }\end{array}$ & 2.38 & .187 & Moderate \\
\hline $\begin{array}{l}\text { 25. Encourage guests to take home their } \\
\text { leftover food. }\end{array}$ & 2.98 & .206 & Moderate \\
\hline \multicolumn{4}{|l|}{ Sent to disposal } \\
\hline 26. Compost organic kitchen waste. & 2.93 & .188 & Moderate \\
\hline 27. Practice food waste segregation. & 3.67 & .159 & High \\
\hline 28. Pursuit food waste reduction programme. & 3.69 & .158 & High \\
\hline 29. Have a waste management team. & 3.29 & .175 & Moderate \\
\hline 30. Conduct a food waste audit. & 3.07 & .178 & Moderate \\
\hline
\end{tabular}

Hotels cater food and beverage services not only to house guests, but also to the outsiders. Hence, hoteliers need to have a systematic process on storage to avoid the spoilage of food. Table 3 shows that most of the hoteliers pursue first in first out (FIFO); labelling food ingredients that show the product expiry dates, and storage instructions in order to avoid damaged raw food ingredients in the storage. These practices also control the stock of raw food ingredients effectively with the right rotation (Halloran et al., 2014). In addition, stored fresh food ingredients at the appropriate temperatures will also prevent food waste. Table 3 shows that the interpretation score for all the items for the process of storage is high, which is above mean 4.31 .

Table 3 shows that the mean interpretation of all items for the process preparation of food is high except item 14 (moderate), which means only a few hoteliers reuse quality leftover food. The results indicate that even though the hoteliers have taken every possible effort to minimise their food wastage when preparing food, they still cannot fully avoid leftover food wastage due to the strict hotel policy and food safety standards. Based on food safety standards, hotels' food items should not be left on the buffet table for more than four hours and should be thrown away even though those food are still in good quality condition (Papargyropoulou et al., 2016). For safety and hygienic purposes, leftover food from the buffet breakfast should not be reused for other meals or served again to their staff hotel during lunch time. In fact, a selection of the type of food quality, packaging, and storage at appropriate temperatures are influenced by prolonging the quality of leftover food for safe consumption or reuse for preparing other meals. The above finding is consistent with the study by Pirani and Arafat (2015) who found that while food safety standards of hotels ensures the food served is 
Saraswathy Kasavan, Ahmad Fariz Mohamed, \& Sharina Abdul Halim

Sustainable Food Waste Management in Hotels: Case Study Langkawi Unesco Global Geopark

fresh and harmless for the guests, but generates a certain amount of buffet leftover waste.

Based on Table 3, an interpretation of mean for all items for the process of serving food is high, which is above mean 3.90. The results also indicate that communication is a very important part in pursuing a systematic process for serving food. For example, clear communication between the waiters and guests regarding food ingredients that are used in the menu, cooking method, and serving portion size of the menu can be avoided in the event of a wrong menu order. In addition, communication between waiters and chefs regarding food menu ordering and number of guest orders is also required. Those clear communications will be helpful to avoid preparing excess quantities of food and preparation food waste. Furthermore, providing various portions of dishes (such as big, medium or small) for guests to choose the size of dishes helps to reduce plate waste. The findings of this study are supported by Kallbekken and Saelen (2013) who found that hoteliers are able to reduce food waste by $19.5 \%$ by reducing portion of dishes using smaller size of plate.

The mean interpretation of all items for the process of management of leftover food and guests' plate waste is moderate, which is below mean 3.02. The results indicate that the strict policy of hotels influences the process management of leftover food and guests' plate waste. In order to follow the hotel's policy, hoteliers (especially big hoteliers) do not allow staff to take anything from their hotels even though there is leftover food or guests' plate waste. Moreover, hoteliers also do not encourage their guests to take away excess plate food ('a la carte') for safety and hygienic purposes. In addition, tasteless food (error in the recipe) or food that does not meet their expectations also increases guests' plate waste. Sometimes, hoteliers prepare extra quantity of food to avoid last minute cooking for guests who arrive without any booking or reservation. However, such practice results to creating higher leftover food waste. Besides that, this study found that guests' food consumption pattern also influences the practices towards sustainable food waste management and this is beyond the control of hoteliers. Guests expect to have a variety of food on their tables, especially during buffet. The hotel, consequently, offers a variety of foods to meet the guests' satisfaction. But unsustainable guests' food consumption pattern leads to generating a lot of plate waste. According to Food Wise Hong Kong (2013), plate waste could be reduced by education or raising awareness among guests through an effective communication program. On the other hand, studies done by Jeffery et al. (1994) and, Kuo and Shih (2016) found that overall average plate waste could be reduced significantly by using coercion approach (include penalty) compared to education approach. Thus the best might be to use both approaches to increase guests' awareness.

The mean interpretation of all the items sent for disposal is moderate. Compost is one of the sustainable practices before food waste is sent to the 
PLANNING MALAYSIA

Journal of the Malaysia Institute of Planners (2017)

landfills. The practice of compost shows it is still moderate (Table 3). The finding in this study on compost concurs to findings by Sullivan and Smith (2014) that explain capital and labour intensive in tropical settings, supportive management, and a market for the compost influenced compost practices. Composting practices are attractive options for island hotels to reduce the costs of managing food waste and are good source for landscaping purposes. According to the Environment Protection Agency (2010), composting system at hotels has a capacity to reduce $44 \%$ of waste costs. In addition, the separation of waste is the starting point for disposal of food waste in a sustainable way. The results indicate that $95 \%$ of the hotels have not implemented a waste audit or established a special team for waste management needs as shown in items 29 and 30 (Table 3).

There are several possible explanations for this overall result. First, the main finding to emerge from this study is that, the lack of concern in hotel policy for food wastage, in which influences the practices towards sustainable food waste management. The results of this study indicate that most of the big hoteliers (4 star and 5 star hotels) have strict hotel policy and food safety standards, which emphasise on safety and standard hygiene purposes but lack of concern about food waste reduction. While most of smaller hoteliers ( 1 star to 3 star hotels) were more flexible with various situations and were more concern in reducing leftovers food waste. The second major finding from this study is that the unsustainable guests' food consumption pattern also influences sustainable food waste management practices for all type of hotels. As found by Stuart (2009), culture, personal choice and socio-demographic characteristics have been associated with increased food wastage. For hotel sector, guests arrivals from different cultures, background and personal taste, will determine the consumption of different types of food, which will affect food waste generation. Thus, hoteliers should take possible actions in convincing and encouraging their customers towards plate waste reduction.

\section{CONCLUSION AND RECOMMENDATIONS}

Hoteliers have difficulty to achieve zero food waste in their hotels because it is a common characteristics for the hospitality sector (Sandaruwani \& Gnanapala, 2016). However, sustainable food waste management among the business operations of the hotel sector can reduce maximum food waste from purchasing until disposal. This sustainable practice will lead to the efficient use of resources relating to foodstuff and helps to reduce operational cost. Apart from the internal management, hoteliers need good cooperation with stakeholders such as customers, other hoteliers, suppliers, NGOs, government and communities, which are important to achieve sustainable food waste management in the hotel sector (Thi, Kumar, \& Lin, 2015).

From the findings, some recommendations are put forward in the pursuit of sustainable food waste management practice in the hotel sector. These 
Saraswathy Kasavan, Ahmad Fariz Mohamed, \& Sharina Abdul Halim

Sustainable Food Waste Management in Hotels: Case Study Langkawi Unesco Global Geopark

recommendations provide the platform for developing guidelines and strategies to improve food waste management practice in the hotel sectors.

- Hoteliers should provide fresh and quality food to meet guests' expectations and satisfaction. At the same time, hoteliers should encourage their guests to reduce plate waste. For example, effective communication helps to raise guests' awareness on reducing food waste or preventing over-ordering of food. Other than that, notice boards, written messages or instructions are used to remind customers to reduce plate waste.

- Hoteliers should establish a specific internal audit team and audit food waste generation by measuring the present food waste levels and identify the key sources of food waste generation. Such practices give useful information for hoteliers to implement effective strategies to reduce food waste before food waste is sent to landfills for disposal.

- Hoteliers should provide training to staff on sustainable food waste management from purchasing to disposal in order to instil and educate staff with food waste reduction culture.

- Hoteliers should develop a food waste management policy with clear objectives, procedures, and goals towards reduction of food waste, and at the same time, maintaining the safety and standard hygiene purposes. In other words, hotel policy for food waste reduction should target the circumstances and actions that lead to food wastage and to facilitate the culture of reduce waste in the hotel operation.

- Competitors (other hoteliers) should cooperate to reduce food waste. For example, a win-win situation could be formed if all hoteliers (all competitors) together make a practice of extra charging the customers who leave food on their plates. These practices would help to reduce plate waste, prevent over-ordering, and at the same time, cut down operational costs.

- The government and non-governmental organisations (NGOs) should promote reduce waste awareness by promoting more programmes and campaigns continuously to all types of hoteliers, guests and also to the local communities.

- The government and non-governmental organisations (NGOs) should encourage green practice (including sustainable food waste management) by giving out awards and helping to promote those hotel names internationally.

- Basically, a minimum of 6 criteria requirements are needed for the rating of hotels in Malaysia, such as qualitative and aesthetic requirements; available common areas; quality and atmospheric bedrooms; quality of varied services; safety and standard hygiene; and professionalism of the hotel staffs (Ministry of Tourism and Culture Malaysia, 2013). The 
Ministry of Tourism and Culture Malaysia should also consider the criteria regarding sustainable food waste management as a requirement aspect for the star rating of hotels in Malaysia.

\section{REFERENCES}

Agamuthu Pariatamby, \& Nagendran Periaiah (2007). Waste management challenges in sustainable development of islands. Retrieved from http://www.iswa.org/uploads/tx_iswaknowledgebase/Pariatamby.pdf

Ahmad, J. (2002). Pemupukan budaya penyelidikan di kalangan guru di sekolah: Satu Penilaian. Bangi: Universiti Kebangsaan Malaysia.

Azizan Marzuki, Shardy Abdullah, Mastura Jaafar, Diana Mohamad, M. M. I. (2016) Kajian daya tampung sosial dan ekonomi bagi pelancongan di Pulau Langkawi. Tanjong Malim: Penerbit Universiti Pendidikan Sultan Idris.

Bohdanowicz, P. (2005). European hoteliers' environmental attitudes: Greening the business. The Cornell Hotel and Restaurant Administration Quarterly, 46(2), 188-204.

Environment Protection Agency. (201). Case studies of organisations managing food waste properly. Retrieved from http://www.envirocentre.ie/includes/images/Case-Studies-of-OrganisationsManaging-Food-Waste-Properly.pdf

Halloran, A., Clement, J., Kornum, N., Bucatariu, C., \& Magid, J. (2014). Addressing food waste reduction in Denmark. Food Policy, 49, 294-301.

Jeffery, R. W., French, S. A., Raether, C., \& Baxter, J. E. (1994). An environmental intervention to increase fruit and salad purchases in a cafeteria. Preventive Medicine, 23(6), 788-792.

Kallbekken, S., \& Sælen, H. (2013). "Nudging" hotel guests to reduce food waste as a win-win environmental measure. Economics Letters, 119(3), 325-327.

Kasim, A. (2009). Managerial attitudes towards environmental management among small and medium hotels in Kuala Lumpur. Journal of Sustainable Tourism. http://doi.org/10.1080/09669580902928468

Kasimu, A. B., Zaiton, S., \& Hassan, H. (2012). Hotels involvement in sustainable tourism practices in Klang Valley, Malaysia. International Journal of Economics and Management, 6(1), 21-34.

Kuo, C., \& Shih, Y. (2016). Gender differences in the effects of education and coercion on reducing buffet plate waste. Journal of Foodservice Business Research, 8020(May), 1-13.

Langkawi Development Authority [LADA] (2017). Laporan Tahunan Lembaga Pembangunan Langkawi.

Mensah, I., \& Blankson, E. J. (2014). Commitment to environmental management in hotels in Accra. International Journal of Hospitality \& Tourism Administration, $15(2), 150-171$.

Ministry of Tourism and Culture Malaysia. (2013). Minimum requirements for star rating of hotel 1.

Molina-Azorín, J. F., Claver-Cortés, E., Pereira-Moliner, J., \& Tarí, J. J. (2009) Environmental practices and firm performance: an empirical analysis in the Spanish hotel industry. Journal of Cleaner Production, 17(5), 516-524. 
Saraswathy Kasavan, Ahmad Fariz Mohamed, \& Sharina Abdul Halim

Sustainable Food Waste Management in Hotels: Case Study Langkawi Unesco Global Geopark

Mourad, M. (2016). Recycling, recovering and preventing "food waste": Competing solutions for food systems sustainability in the United States and France. Journal of Cleaner Production, 126, 461-477.

Ong, P. L., Nurhafizah Yusoff, \& Sharina Abdul Halim. (2010). Menjejak semangat 'Kawi': Langkawi sebagai geopark. Akademika, 80, 55-68.

Papargyropoulou, E., Wright, N., Lozano, R., Steinberger, J., Padfield, R., \& Ujang, Z. (2016). Conceptual framework for the study of food waste generation and prevention in the hospitality sector. Waste Management, 49, 326-336.

Pirani, S. I., \& Arafat, H. A. (2015). Reduction of Food Waste Generation in the Hospitality Industry. Journal of Cleaner Production. http://doi.org/10.1016/j.jclepro.2015.07.146

Sandaruwani, J. A. R. C., \& Gnanapala, W. K. A. C. (2016). Food wastage and its impacts on sustainable business operations: a study on Sri Lankan tourist hotels. Procedia Food Science, 6(2015), 133-135.

Shamshiry, E., Nadi, B., Mokhtar, M., Komoo, I., Saadiah Hashim, H., \& Yahaya, N. (2011). Integrated models for solid waste management in tourism regions: Langkawi Island, Malaysia. Journal of Environmental and Public Health, 2011 $1-5$.

Sharina Abdul Halim, Ong, P. L., Nurhafizah Yussof, \& Lim, C. S. (2011). Participation towards heritage conservation: Case of fishing community in Langkawi Geopark. Planning Malaysia, (1), 185-196.

Stuart, T. (2009). Waste: uncovering the global food scandal. New York: W.W. Norton \& Company.

Sullivan, K., \& Smith, J. (2014). Recycling for small island tourism developments : Food waste composting at Sandals Emerald Bay, Exuma, Bahamas. Resources, Conservation \& Recycling, 92, 25-37.

Tan, K.C., Lyman, S. B., \& Wisner, J. D. (2002). Supply chain management: a strategic perspective. International Journal of Operation \& Production Management, 22(6), 614-631.

Thi, N. B. D., Kumar, G., \& Lin, C.-Y. (2015). An overview of food waste management in developing countries: Current status and future perspective. Journal of Environmental Management, 157, 220-229.

Tourism Malaysia. (2017). Malaysia tourism statistics in brief.

Wang, L. en, Liu, G., Liu, X., Liu, Y., Gao, J., Zhou, B., ... Cheng, S. (2017). The weight of unfinished plate: A survey based characterization of restaurant food waste in Chinese cities. Waste Management, 66, 3-12.

Food Wise Hong Kong (2013). Food waste reduction good practice guide for hotel sector.

WRAP (2011). The composition of waste disposed of by the UK hospitality industry (Final Report). 